\title{
READYNESS OF STUDENTS OF PEDAGOGICAL UNIVERSITY TO THE IMPLEMENTATION OF DISTANCE LEARNING
}

\author{
Olha Voloshina ${ }^{1}$, Yaroslav Haleta ${ }^{2}$ \\ 1Ph.D. (Pedagogy), Methodist of the Department of Pedagogy, Psychology and Correctional Education of \\ KZ "Kirovohrad Regional Institute of Postgraduate Pedagogical Education named after Vasyl \\ Sukhomlynsky", Kropyvnytskyi, Ukraine, e-mail: mikka071986@gmail.com ORCID: https://orcid.org/0000- \\ 0001-8226-8681Ab \\ ${ }^{2}$ Doctor of Sciences (Pedagogy), Professor, Central Ukrainian State Pedagogical University named after V. \\ Vynnychenko, Kropyvnytskyi, Ukraine, e-mail: yaroslavhaleta@ukr.net, ORCID: https://orcid.org/0000- \\ 0003-0484-529X
}

Abstract. Distance learning is a way of obtaining education using computer and modern information technologies, which allows students to study at a distance. Informatization of the educational process and the latest information and communication technologies, provided they are fully used and introduced into the educational process, radically change the course of society. In the process of distance learning distance courses are used - information products that are sufficient for learning in certain disciplines.

One of the priority areas of the modernization program of secondary and higher schools is distance learning. In modern conditions, there is a need for higher education by distance, which is caused by the need to study full-time, educated by people with disabilities and those who are abroad or in prison. This opportunity is provided by distance learning, which is carried out through information and educational technologies and communication systems.

Distance learning has a number of undeniable advantages. In particular, a higher education applicant can study at a time convenient to him, in a familiar environment and at a relatively autonomous pace. The lower cost of such training should also be taken into account, as there is no need to rent premises, pay a significant number of staff and save time.

In the case of distance learning, the active role of the teacher is not reduced, as he must determine the level of knowledge of the applicant, and decide to adjust the curriculum in order to achieve the best mastery of the material. If necessary, the student can get advice from the teacher, communicating with him online, directly using the Internet as a means of communication (web-chat, IRC, ICQ, interactive TV, web-telephony, Telnet). The MOODLE system is successfully used for successful distance learning.

Keywords: Distance learning, distance interactive learning SCORM, MOODLE, Internet technologies.

JEL Classification: I0; I20

Formulas: 0; fig .: 0; tabl .: 0; bibl .: 11

Introduction. Currently, the transition to new educational standards of higher education increases the importance of independent work of students. Up to $70 \%$ of the total training time for bachelors and masters can be allocated for independent work. This requires teachers to develop appropriate teaching materials. Also recently, retraining of specialists and additional specialization of students has become increasingly important. It is necessary to teach future professionals to acquire knowledge independently. These trends will inevitably lead to the emergence of a large number of courses aimed at preparing professionals for the free search for knowledge in the global information space, which is very important for competitiveness [7].

Experts from the UNESCO Institute for Information Technology in Education conducted a sociological study that showed that people's educational needs are 
accompanied by such requirements for learning conditions (distance, openness, flexibility, individualization) that can be met only by using models, forms, methods and technologies of learning , based on the widespread use of information and communication technologies [8].

Literature review. The works of many foreign scholars, such as R. Delling, G. Ramble, D. Keegan, M. Simonson, M. Moore, A. Clark, and M. Thompson, are devoted to the problems of distance education. and respectively domestic, such as: O. Andreev, G. Kozlakova, I. Kozubovska, V. Oliynyk, E. Polat, A. Khutorsky. But despite the large number of scientific studies, modern distance education in Ukraine resembles traditional forms of distance learning, without using all the possibilities of fundamentally new forms and methods of teaching [5].

Many scientists deal with the implementation and use of information and communication technologies in higher education, in particular: A. Andreev, T. Vakhrushcheva, M. Zagirnyak, V. Kukharenko, E. Polat, A. Khutorsky, I. Kozubovska, O. Rybalko, E. Dolynsky, M. Bukharkina, J. Vagramenko, V. Verzhbitsky, K. Verishko, V. Kaimin, V. Soldatkin, N. Syrotenko, N. Korsunska, O. Skubashevska V. Osadchy and others. Distance learning has become widespread in many countries around the world and its popularity is growing rapidly every year [2].

In recent years, distance learning has become widespread in Ukraine, in particular the leading positions in this regard are occupied by KNTEU and IAPM, where the introduction of new educational technologies and their introduction into the organizational channel in the form of new social institutions such as TV universities, tutoring and information centers. advanced training and retraining, etc., allows everyone, even in a systemic crisis and a sharp reduction in financial resources, to receive proper education and obtain the desired specialty. These forms of distance learning open new perspectives for the development of students' self-education [4].

Aims. The purpose of the article is to determine the role of distance learning in the system of higher education in Ukraine, the main advantages and problems of developing and implementing distance learning courses.

Methods. The study uses empirical and systematic approaches, methods of analysis and synthesis, according to which you can determine the necessary set of technologies that can provide the educational process, using distance learning methods.

Results. The development of information technology and global networks allows to introduce into the training process elements of distance learning, starting with the presentation of material in the form of Internet lectures and ending with the current and even final control, which allows you to most conveniently organize work in these areas. To meet the needs described above, it is necessary to train professionals who can work in distance learning.

An important condition for the implementation of distance learning, according to AI Kuzminsky, is compliance with academic quality standards in program development. The process of creating a program or any of its modules should include: 
1. Full compliance with academic standards.

2. Identify the minimum academic needs of the program, describe theseneeds so that they are understandable to potential students.

3. Review of final testing strategies, including the determination of its impact on learning outcomes within the program or module.

4. Description of the relationship between learning strategies, objectives and expected results.

5. Implementation of the process of quality control of the main components of the program [6].

A higher education institution that offers distance learning must:

1. Take into account the skills, knowledge and experience of the student and the conditions in which he will study using distance learning systems.

2. Determine the basis for the choice of teaching aids.

3. Consider in detail and determine the teaching materials and other teaching aids that will be offered to the student through the institution that provides distance learning services.

4. Get acquainted with the structure of educational materials and make sure that it ensures the achievement of the desired results.

5. To consider the extent to which educational materials are filled with interactive potential and contribute to the assimilation of a certain amount of knowledge by students.

6. Make a detailed schedule of classes in a specific curriculum, using a distance learning planning system.

7. Conclude an action program for the institution providing distance learning [6].

Unlike foreign models, Ukrainian distance education is closer to our consumers and is more democratic. Organically combining mixed technologies of open education (case technologies, network technologies), Ukrainian distance education becomes the most accessible to the general public, making it possible to get education not for life, but for life [3]. Nowadays, the interactive interaction of the teacher with students is promising with the help of information and communication networks, from which the environment of Internet users stands out en masse. In 2003, the ADL initiative group began developing a standard for distance interactive learning SCORM, which involves the widespread use of Internet technologies. The introduction of standards contributes to the deepening of the requirements for distance learning and software requirements.

The following basic elements are used during distance learning:

- distance learning courses;

- web pages and sites;

- Email;

- forums and blogs;

- TV and video conferencing;

- virtual classrooms, etc. 
Particular attention in the training of future teachers should be paid to distance learning, a distinctive feature of which is the lack of unity of space and time in the interaction between teacher and students.

The relevance of this is due to the use of distance learning platforms in educational institutions, such as LCMS Moodle for organizing testing of students, conducting additional training sessions during quarantine, etc. [1].

The spread of cloud services for working with data (Office 365, GoogleDrive), the use of social networks and other Web 2.0 services (Twitter, Youtube, Wiki, blog sites, etc.) has increased the use of information technology in the learning process and necessitated the use of these services to develop more diverse and attractive e-course content [11].

Distance learning technologies include work with an electronic textbook, e-mail, thematic forums and chat conferences, webinars.

The electronic textbook is used for independent study of theoretical material on the discipline.

Webinars are a special type of video conferencing that simultaneously provides two-way transmission, processing, conversion and presentation of interactive information at a distance in real time. Webinars are more used to convey learning material, because this system minimizes audience feedback [11].

In the process of learning, students should get an idea of techno-trends in education - cloud technology, Big Data, BYOD (Bring Your Own Device), gamification of education, robotics, augmented reality (augmented), inverted classroom, STEM-education, SMART, Internet of Things, 1 computer: 1 student. Also, learn to use Web 2.0 services, namely Learning Apps - a tool for creating educational games, Tagul, Many Eyes, Word It Out, Wordle, Tagxedo-Creator services for creating word clouds and Google Sites [11].

Discussion. In the pedagogical literature there is still no holistic view of distance learning and readiness for its implementation. Considering the structure of student readiness for the implementation of distance learning as a unity of components [10], we assess the degree of its development by the following criteria: 1) motivational and cognitive readiness for the implementation of distance learning; 2) technological readiness for the implementation of distance learning; 3) reflexive and effective assessment of distance learning activities.

Each criterion is disclosed by us through the relevant indicators by which we can assess the level of its formation: motivational and cognitive readiness for distance learning (motivation; knowledge of distance learning; attitude to distance learning; knowledge of options for distance learning); technological readiness for the implementation of distance learning (mastery of methods of implementing distance learning; mastery of techniques and methods of distance learning; the ability to use modern information technology; knowledge of the basic educational resources of the Internet; reflexive-effective assessment of distance learning activities (inclusion in distance learning activities; reflection on distance learning implementation).

We specify the proposed criteria in terms of their manifestation in groups with low, sufficient and high levels of readiness for the implementation of distance 
learning. Motivational and cognitive readiness for the implementation of distance learning. The low level is characterized by unformed needs and interests, the minimum amount of knowledge, skills and abilities necessary for the implementation of distance learning. Students' interest in gaining new knowledge is due only to the need to pass the exam. This level is characterized by the formation of only the foundations of beliefs and ideals. Students in this group have difficulty producing individual critical judgments about the distance learning system. They do not have the techniques to formulate their own distance learning goals. The creative direction of this activity is poorly developed. A sufficient level is characterized by an increase in creative activity of students. Interest in acquiring new knowledge is the basis for the development of a system of needs and interests. A significant amount of knowledge, skills and abilities required for the implementation of distance learning, knowledge is productive. Students consciously perceive information, competently operate with concepts. However, the appeal to extracurricular material is still episodic. Students in this group are more confident in the adequacy of their own views on the distance learning system that exists in the world. They are able to formulate and argue the purpose of their activities in the distance learning system. Criteria for assessing the phenomena that occur are becoming deeper, more flexible and more diverse. The creative direction of activity intensifies. The need to realize their beliefs is realized from the standpoint of public importance. The high level is characterized by the highest creative activity, developed a wide system of stable and focused needs and interests, the ability to assess the processes occurring in the system of distance learning, and phenomena based on individually understood and personally accepted values. Students of this group regularly read literature on the specialty, have full knowledge, skills and abilities necessary for the implementation of distance learning. Students of this group are characterized by a high degree of formation of a system of views and attitudes to the processes that actually take place in the system of distance learning, the integrity of value orientations and attitudes, which is consciously embodied in the process of their distance learning. Students of this group are autonomous and independent in their assessments and judgments about the phenomena and processes in the field of distance learning. Consciously and responsibly choose the purpose of their activities and socially acceptable means of achieving it, able to actively defend their beliefs and position in a situation of struggle of values and meanings, have the techniques of creative self-development.

The levels of formation of technological readiness for information activities can be represented as follows.

Low level. Students are not familiar enough with the methods of distance learning, do not have the techniques to formulate their own goals for the implementation of distance learning. Their motivational sphere is dominated by situational needs and motives, vague interest. They have difficulties in the creative application of knowledge, skills and abilities in solving specific initial and professional tasks. Computer skills in the process of formation.

Sufficient level. Students in this group are well versed in the system of distance technology. They understand the importance of studying distance learning 
technologies. The motivation of their activities for the implementation of distance learning is focused on individual success and self-affirmation in the eyes of members of the reference group (classmates, teachers, parents). They try to solve the tasks set before them in different ways, show activity and initiative. They successfully use the information obtained when creating distance learning courses, persistently struggle with difficulties and try to offer their way to solve various problems.

High level. Students of this group are fluent in the system of distance technology. They can independently develop a distance learning course, feel the need for self-knowledge, self-development and the fullest realization of their creative potential and individual abilities in the distance learning system. The main motives of their activities are future high professional achievements, which they consider in terms of their maximum usefulness to others and society. They have computer equipment and new information technologies, freely, consciously and creatively use the acquired knowledge and skills in solving educational and professional tasks, have their own individual style when working in the field of distance learning. Regarding the level groups, the characteristics of the reflective and productive assessment of information activities were distributed as follows. The low level of involvement in the implementation of distance learning is characterized by a focus on obtaining only personal emotional satisfaction from work in the field of distance learning. The level of claims to the quality, content of distance learning is low. The distance learning system in most cases is seen as a subject that causes only emotional satisfaction. Manifestation of social, higher feelings is poorly developed and does not play a significant role in actions and deeds. For a sufficient level of involvement in the implementation of distance learning is characterized by the regulatory role of higher social feelings. A person is able to critically evaluate, determine the quality of distance learning. Distance learning is considered primarily as a subject to meet cognitive needs. Work in the distance learning system is accompanied by a sense of psychological comfort, confidence and is associated with improving social status and skills. Emotional activity takes on a more complex form. Here plays a role and the expansion of the content of feelings and emotions, and their value orientation. For a high level of inclusion in the implementation of distance learning is characterized by the integrity of its structure and content, which differs in depth and comprehensive development. Emotional activity becomes a tool for creative development, consumption and use of distance learning methods. Students of this group regulate their activities for the implementation of distance learning with the help of higher senses - intellectual, moral and aesthetic. At this level, emotional activity serves as a regulator of the value orientation of human feelings and emotions. These criteria, indicators and levels of readiness for the implementation of distance learning serve as initial data for determining the levels of development of this quality in students of pedagogical universities. The question of determining the levels of development (formation) of personal qualities and qualities has always attracted the attention of teachers and psychologists (LI Bozhovich, GO Bokareva, OS Grebenyuk, VS Ilyin, OM Leontiev, V D. Shadrikov, GI Schukin). In accordance with the above criteria and in agreement with ES Polat [9], we put forward a number of requirements, the 
implementation of which will ensure the readiness of students of pedagogical universities to implement distance learning:

Motivational and cognitive readiness for the implementation of distance learning (knowledge of the principles of personal computer and peripherals; knowledge of the basic principles of the Internet, software ownership; knowledge of teaching materials and scientific literature on the use of the latest information technology in learning; understanding the possibilities use of computer to control the learning process, knowledge of the basic types and general principles of telecommunications systems, understanding the features of connecting users with different levels of Internet access, knowledge of the organization and conduct of teleconferences, knowledge of telecommunications etiquette, knowledge of individual styles of educational activities distance learning, knowledge of the factors that determine the learning activity of students in terms of distance learning, knowledge of the peculiarities of the process of learning distance learning conditions; knowledge of the peculiarities of the organization of independent work of students in the information-cognitive environment of the Internet; knowledge of modern personality-oriented teaching methods - the method of collaborative learning, the method of projects, the research method, etc .; knowledge of the principles of personal computer and peripherals; knowledge of the basic principles of work on the Internet, possession of software; knowledge of methodical materials and scientific literature on the problem of using the latest information technologies in education; understanding the possibilities of using a computer to manage the learning process; knowledge of the basic types and general principles of functioning of telecommunication systems; understanding the features of connecting users with different levels of Internet access; knowledge of the peculiarities of organizing and conducting teleconferences; knowledge of telecommunication etiquette; knowledge of individual styles of educational and cognitive activity of students under the condition of distance learning; knowledge of the factors that determine the educational activity of students in terms of distance learning; knowledge of the peculiarities of the process of knowledge acquisition under the condition of distance learning; knowledge of the peculiarities of the organization of independent work of students in the information-cognitive environment of the Internet; knowledge of modern personality-oriented teaching methods - the method of collaborative learning, the project method, the research method, etc. Technological readiness for the implementation of distance learning (the ability to use various means of telecommunications (e-mail, teleconferencing, realtime communication, etc.) to share information with other users, skills of information "navigation" in the network, the ability to work with network information resources ( network databases, information services, etc.); the ability to understand the features of the use of software tools for creating distance learning courses; the ability to work with e-mail; the ability to dialogue with other network users; the ability to work with modern hypertext and hypermedia systems; available on the Internet those information resources that are most adequate to the objectives of training, the ability to prepare information for transmission over the network using various programs (text editor, graphic editor, NTML editor) and the necessary utilities (archivers, co 
blowers and the like); mastery of methods of organizing communication of distance learning participants; ability to organize and conduct psychological and pedagogical testing of students; ability to compose an individual psychological and pedagogical portrait of a student; ability to provide psychological support to students in the initial stages of educational activities; ability to form small study groups on the principle of psychological compatibility; ability to conduct current psychological and pedagogical diagnostics of a virtual study group; ability to maintain a favorable psychological climate in the middle of a virtual study group; ability to prevent conflict situations; mastery of individual, group and frontal teaching methods; ability to adapt full-time teaching methods to the conditions of the Internet; ability to combine full-time and part-time forms of distance learning; ability to combine individual and frontal-group forms of learning when working with distance students; ability to organize and conduct a telecommunications project; ability to organize and conduct an educational thematic teleconference. Reflexive and effective assessment of distance learning activities (ability to organize and monitor student learning activities; ability to organize an effective system of control and testing of students; ability to organize and evaluate reflection of students' learning activities. Most of the above requirements are met by students majoring in Informatics. it is necessary to organize a special course and a special seminar on the problem of distance learning, within which students will master the principles of work in the distance learning system, as well as be able to try themselves as someone who remotely is studying, and in the role of the organizer of a distance learning course. To determine the program of the special course and special seminar, we will try to identify the main actions necessary to form the readiness of future teachers to work in the distance learning system.

Conclusions. After analyzing the activities of teachers working in the field of distance learning, we came to the conclusion that to form the readiness of the student to implement distance learning it is necessary to create the following pedagogical conditions:

1. To form the future teacher's motivation to implement distance learning. We believe that emphasis should be placed on the relevance, convenience and high cost of distance learning compared to the traditional form of learning.

2. Involve the future teacher in distance education as a student.

3 . Teach the future teacher to create distance learning courses. The process of creating courses consists of four stages - planning, selection, preparation of tools for distance learning and forecasting the result.

4. Organize distance educational activities for the future teacher as an intern to practice basic skills, gain experience and assessment from the supervising teacher; and then as a teacher to form their own style of creating and conducting distance learning courses.

5. Evaluate the result. To obtain an objective answer, it is necessary to conduct both an internal assessment of the result of distance learning activities (carried out by the teacher) and external (consists of the answers of students to the question of reflection). 
6. Adjust the activities for the implementation of distance learning by the future teacher of distance learning in accordance with the results of the analysis of the distance learning course. We assume that the selection of the following stages of preparation for the implementation of distance learning will help to more accurately describe the process of readiness: defining the goals and objectives of the distance learning course based on the program, manuals, school textbook and additional literature; selection of the optimal content of the material of the distance learning course, its division into a number of semantically complete blocks, parts, allocation of basic knowledge, didactic processing; selection of the main material; development of the structure of the distance learning course, determination of the most expedient methods and techniques of teaching; finding connections of this material with other subjects and use of these connections at studying of new material and at formation of new knowledge and abilities of learners; planning of all actions of the teacher and those who study at all stages of a distance learning course and, first of all, at mastering of new knowledge and abilities, and also at their application in standard situations; selection of didactic means of the distance learning course; inspection of equipment and technical means of training; anticipation of the scope and forms of independent work of distance learning students and its focus on the development of their independence; determination of forms and methods of consolidation of acquired knowledge and acquired skills in the course of distance learning and beyond, methods of generalization and systematization of knowledge; compiling a list of students whose knowledge will be tested by appropriate forms and methods, taking into account the levels of their formation; planning to test the skills of students; determining the content, scope and forms of homework, thinking about methods of homework; thinking of forms of summarizing the results of the distance learning course; recording the plan and course of the distance learning course for further analysis and correction. Thus, we believe that the training of teachers who are able to work in the system of distance learning can be carried out during their training in higher education within the specially organized for this purpose courses and seminars. The criteria, indicators and levels formulated by us allow us to assess the readiness of the future teacher to implement distance learning.

Author contributions. The authors contributed equally.

Disclosure statement. The authors do not have any conflict of interest.

References:

1. Batsurovskaya, I. (2010), Tekhnolohiyi dystantsiynoho navchannya u vyshchyy osviti [Technologies of distance learning in higher education] [Electronic resource], Access mode: http://www.confcontact.com/20110225/pe4_samojl.htm [in Ukrainian].

2. Bikov, V. (2015), Dystantsiyne navchannya v krayinakh Yevropy ta SSHA i perspektyvy dlya Ukrayiny [Distance learning in Europe and the United States and prospects for Ukraine], Academy of Pedagogical Sciences of Ukraine, Institute of Teaching, pp. 77-144 [in Ukrainian].

3. Veremchuk, A. (2013), Problemy i perspektyvy dystantsiynoho navchannya u vyshchykh navchal'nykh zakladakh [Problems and prospects of distance learning in higher education], Problems of training a modern teacher, № 7, pp. 319-325 [in Ukrainian].

4. Klokar, N. (2012), Metodolohichni osnovy zaprovadzhennya dystantsiynoho navchannya v systemi pidvyshchennya kvalifikatsiyi [Methodological bases of introduction of distance learning in the system of advanced training], Way of education, № 4 (46), pp. 38-41 [in Ukrainian]. 
5. Kontseptsiya rozvytku dystantsiynoyi osvity $\mathrm{v}$ Ukrayini [The concept of development of distance education in Ukraine] (approved by the Resolution of the Ministry of Education and Science of Ukraine, (2000) [in Ukrainian].

6. Mukoviz, O., (2016), Osnovy organizatsii distantsiinoho navchannia u sistemy neperervnoi osviti, [Fundamentals of distance learning in the system of continuing education] [methodical recommendations], Uman, 66 p. [in Ukrainian] .

7. Polozhennya pro dystantsiyne navchannya [Regulations on distance learning], (2004), (Approved by the order of the Ministry of Education and Science of Ukraine 21.01.2004 № 40) [Electronic resource] // Access mode: http://zakon4.rada.gov.ua/laws/show/z0703-13\#n18 [in Ukrainian].

8. Sostoyaniye obrazovatel'nykh potrebnostey vzroslogo naseleniya krupneyshikh stran SNG i vozmozhnostey ikh realizatsii posredstvom tekhnologiy DO/ Distantsionnoy obucheniya v stranakh SNG. Monitoring obrazovatel'nykh potrebnostey i vozmozhnostey. Analiticheskiy obzor [The state of educational needs of the adult population of the largest CIS countries and opportunities for their implementation through DO / Distance learning technologies in the CIS countries. Monitoring of educational needs and opportunities. Analytical review], (2003), UNESCO Institute for Information Technology in Education, Moscow, p. 53 [in Russian].

9. Polat, E., Bukharkina, M., Moiseeva, M., (2004), Teoriya i praktika distantsionnogo obucheniya [Theory and practice of distance learning: Textbook. manual for students. higher ped. textbook institutions], $416 \mathrm{p}$ [in Russian].

10. Uznadze, D., (2003), Psikhologiya ustanovki [Psychology of installation], $416 \mathrm{p}$ [in Russian].

11. Shovkun, V., (2016), Vykorystannya dystantsiynykh tekhnolohiy u protsesi pidhotovky maybutnikh uchyteliv informatyky [The use of remote technologies in the process of training future teachers of computer science], Open educational e-environment of modern university, № 2, pp. 281-292 [in Ukrainian]. 